\title{
Association between junk food consumption and fast-food outlet access near school among Quebec secondary-school children: findings from the Quebec Health Survey of High School Students (QHSHSS) 2010-11
}

\author{
Nicoleta Cutumisu ${ }^{1,2, *}$, Issouf Traoré ${ }^{3}$, Marie-Claude Paquette ${ }^{2}$, Linda Cazale ${ }^{3}$, \\ Hélène Camirand ${ }^{3}$, Benoit Lalonde $\mathrm{e}^{2,4,5}$ and Eric Robitaille ${ }^{2}$ \\ 'INRS (National Institute for Scientific Research/Institut national de la recherche scientifique) - Institut Armand \\ Frappier Research Center, 531 Boul des Prairies, Building 12, Office 109, Laval, Quebec, Canada, H7V 1B7: \\ ${ }^{2}$ National Public Health Institute of Quebec (Institut national de santé publique du Québec), Montreal, \\ Quebec, Canada: ${ }^{3}$ Institute of Statistics of Quebec (Institut de la statistique du Québec), Montreal, Quebec, \\ Canada: ${ }^{4}$ Laval University, Quebec City, Quebec, Canada: ${ }^{5}$ Research Centre of the Quebec Heart and Lung Institute \\ (I'Institut universitaire de cardiologie et de pneumologie de Québec - CRIUCPQ), Quebec City, Quebec, Canada
}

Submitted 20 May 2016: Final revision received 18 August 2016: Accepted 25 August 2016: First published online 24 November 2016

\begin{abstract}
Objective: We investigated the association between junk food consumption at lunchtime (JCL) and fast-food outlet access near school among secondary-school children in Quebec.

Design: A geographic information system database was used to characterize the food environment around a sub-sample of 374 public schools in which 26655 students were enrolled. The outcome variable was JCL during the previous week, dichotomized into low JCL (none or once) $v$. high JCL (twice or more). Access to fast-food outlets near school was assessed using an existing database of fast-food outlets in Quebec. Covariates included student (age, sex and self-rated perceived health), family (familial status and parental education) and school (urban/rural status and deprivation) variables. Hierarchical logistic regression models were employed for analyses using PROC GLIMMIX of SAS version 9.3.

Setting: Province of Quebec, Canada.

Subjects: We used data from the Quebec Health Survey of High School Students (QHSHSS) 2010-11, a survey of secondary-school Quebec students.

Results: Exposure to two or more fast-food outlets within a radius of $750 \mathrm{~m}$ around schools was associated with a higher likelihood of excess JCL (OR $=1 \cdot 50 ; 95 \%$ CI $1.28,1.75)$, controlling for the characteristics of the students, their families and their schools.

Conclusions: The food environment surrounding schools can constitute a target for interventions to improve food choices among secondary-school children living in the province of Quebec. Transforming environments around schools to promote healthy eating includes modifying zoning regulations that restrict access to fast-food outlets around schools.
\end{abstract}

The increased prevalence of overweight and obesity in the industrialized countries is an important public health issue $^{(1,2)}$. Being overweight or obese constitutes one of the leading mortality risks around the globe, accounting for 0.7 million deaths equivalent to $8.4 \%$ of the total deaths in the developed countries in $2004^{(3)}$. In Canada, between $8 \cdot 2$ and $12.5 \%$ of the children aged 2-17 years were obese in $2004^{(4)}$. In Quebec, a quarter of children aged
2-17 years were overweight or obese in $2004^{(5)}$. The most recent data indicate that $21 \%$ of youths aged $12-17$ years are overweight or obese ${ }^{(6)}$.

The food intake patterns of Canadian children have been considered partly responsible for the increase in the childhood obesity rates ${ }^{(7)}$. The volume of food sales from food stores as opposed to restaurants has decreased from $75 \%$ of the average household food expenditure in $2002^{(8)}$ 
to $72 \%$ in $2010^{(9)}$, and Canada's fast-food restaurant average annual sales are estimated to continue to grow $^{(10)}$. Therefore, Canadian children not only have more access to food in general, but they also increasingly tend to eat out, which is associated with greater energy intake ${ }^{(11)}$ and with larger portion sizes ${ }^{(12)}$.

Also, the societal changes of the past 50 years have created risk factors associated with obesity ${ }^{(13)}$, including individual-level factors, behavioural factors pertaining to lifestyle and environmental factors ${ }^{(14)}$. Among these factors, environmental factors (i.e. factors related to the natural and the built environment) constitute a promising target for public health interventions ${ }^{(15)}$. Consequently, environmental factors have been studied in relation to childhood obesity in the past decades. However, such studies focused mostly on the association of excess weight and neighbourhood environments. Moreover, school environments have recently garnered attention as environments that may influence the adoption and maintenance of healthy life habits ${ }^{(4)}$. In particular, school environments including built environments within and around schools may be responsible for the nutritional and physical activity opportunities offered to the students ${ }^{(4)}$. For instance, food environments around schools are associated with youths' food consumption and purchasing during lunch ${ }^{(16,17)}$. One study ${ }^{(18)}$ found that eating at least five servings of fruits and vegetables daily was associated with a lower density of fast-food outlets and with a lower ratio of access to fast-food and convenience stores $v$. supermarkets and specialty food stores around $1000 \mathrm{~m}$ of school among students aged 8-10 years living in the Montreal region. Also, recent studies show a higher prevalence of junk food and sugary drinks consumption among children in Quebec; for instance, $11 \%$ of boys and $7 \%$ of girls eat junk food at least three times weekly, while $35 \%$ of boys and $26 \%$ of girls drink sugary soft drinks, eat snacks and sweets at least once daily ${ }^{(6)}$.

More than half of Quebec's public schools (58.9\%) are located within $750 \mathrm{~m}$ of a fast-food outlet, measured along the street networks ${ }^{(19)}$. Children spend a large part of their day on school sites and are, thus, subjected to the school environment's influence ${ }^{(19,20)}$. Therefore, a better understanding of school food environments and their influence on children's food consumption is warranted. However, no study has investigated the role that school contexts play in influencing children's junk food consumption in a large sample collected across Quebec. Elucidating the school context's role in relation to children's junk food consumption will contribute to a better understanding of the determinants of youths' health to guide interventions for ameliorating youths' nutritional options in and around schools across Quebec.

Therefore the present study aimed to investigate the association between junk food consumption during lunchtime (JCL) in the previous week and school fast-food outlet access among secondary-school children in Quebec (aged 12-17 years), after accounting for several covariates such as selected student variables (sex, age and perceived heath), family variables (familial status and parental education), as well as school variables (school status and deprivation), which were consistent covariates of youths' junk food consumption ${ }^{(17,21-24)}$. Junk food refers to foods of poor nutritional quality and rich in energy, which should not be consumed regularly nor should be readily/ easily available in our food environments ${ }^{(25)}$.

\section{Methods}

\section{Data sources}

The study was approved by the Institute of Statistics of Quebec's Ethics Committee. Four databases were used for the present study. The first database was the Quebec Health Survey of High School Students (QHSHSS) 2010-11 survey ${ }^{(26)}$, which provided data on students. It is a representative survey conducted by the Quebec Institute of Statistics (Institut de la statistique du Québec; ISQ) at the request of the Ministry of Health and Social Services (Ministère de la Santé et des Services Sociaux). It focuses on physical health and lifestyle habits, as well as on mental and psychosocial health. The target population consists of secondary-school students in public and private schools, both Francophone and Anglophone. The sampling of the participating schools was random, based on their health region and grade level, in proportion to their size, from all schools with students at each given grade level. Also, the sample was selected to be representative of the province as well as of each of the sixteen Quebec health regions participating in the self-administered computerized survey (two additional regions, Nunavik and Terres-Cries-de-laBaie-James, were not included in this survey), with an additional sample being collected for eight of the selected health regions. Classes were then selected in each school for a given grade level based on a list for a standard social science course, resulting in a selection of multiple classes from the same school, in some instances. The sample consisted of 63196 Quebec secondary-school students. The survey was administered in both French and English between November 2010 and May 2011 by more than forty ISQ interviewers in teams of two in 470 schools and 2651 classes. The participation of the students was on a voluntary basis. Confidentiality was ensured by the ISQ and data access was provided according to the ISQ confidentiality policy. Information on health (e.g. self-rated health, self-reported weight), lifestyle habits (e.g. physical activity, smoking, alcohol and drug use, sexual behaviour) and sociodemographics was collected for the participating students $^{(27)}$. A total of $32000(50 \cdot 7 \%)$ students provided responses regarding their lifestyle habits.

Two other databases were provided by the Quebec Ministry of Education, Recreation, and Sports (MELS), one containing the inventory and location of 374 public 
schools across Quebec in 2014 and another containing their level of socio-economic deprivation ${ }^{(28)}$ in 2009 , based on the Canadian Census.

The fourth database was provided by the Quebec Ministry of Agriculture, Fisheries and Food (MAPAQ), containing data on functioning licences for each food establishment operating in the province of Quebec in $2009^{(19)}$. Three initial food categories described in the inventory were collapsed to create the fast-food outlet category: mobile food stands (i.e. food trucks that sell light food to be eaten at the location or to be taken away), takeout restaurants (i.e. establishments that prepare and sell food to be taken away or delivered) and quick-service restaurants (i.e. specialty-menu establishments with a service counter with or without tables, offering burgers, chicken, hot dogs). Data on the location of 4826 fast-food outlets were then extracted.

\section{Procedures}

We employed a sub-sample of 26655 students enrolled in 374 public schools located across Quebec. We did not include students in private schools because data on the level of school socio-economic deprivation provided by the MELS were created for public schools only. We assembled a geographic information system (GIS) database in which we related individual-level information and built environment information characterizing the surroundings of each public school location. We also employed GIS to derive school access to fast-food outlets information, using the existing MAPAQ database of fastfood outlets in Quebec, as well as to derive information on the school urban/rural status, using Statistics Canada cartographic boundaries ${ }^{(29)}$ of population centres ${ }^{(30)}$, which represent urban concentrations with a population of 'at least 1000 and a population density of 400 persons or more per square kilometre, based on the current census population count. All areas outside population centres are classified as rural areas, ${ }^{,(30)}$.

\section{Variables}

\section{Outcome variable}

The outcome variable was frequency of JCL in the previous week, assessed using students' responses to the following question: 'During the previous week of school (Monday to Friday), how many times did you eat in a restaurant snack foods (such as French fries, poutine, burgers, pizza, pizza pockets, chicken wings, fried chicken, hot dogs, corn dogs) during lunchtime?' Students' responses were then dichotomized into: (i) ' 2 or more times' ('higher JCL'); and (ii) '0 or 1 time' ('lower JCL'). This cut-off was selected based on Laxer and Janssen's work, building on previous research indicating that consuming junk food two or more times weekly is associated with a poorer health status among children ${ }^{(16,31-33)}$.

\section{School-level variables}

School environment variables included the school index of material deprivation, the school urban/rural status and the school index of access to fast-food outlets.

school deprivation. The school index of material deprivation provided by MELS is based on the Canadian Census, using information about families with children aged 0-18 years and about the students' residential neighbourhoods. This index consists of two variables: mother's low level of educational attainment and parental unemployment, which are strongly associated with children's low educational achievement ${ }^{(34)}$. The index was calculated for all public schools, ranging from 1 (low deprivation) to 10 (high deprivation). We then dichotomized the index into 'less deprived' (the three lowest deciles of deprivation) and 'more deprived' (the three highest deciles of deprivation).

School urban/rural status. The school urban/rural status was dichotomized into 'rural' and 'urban' schools. We considered all schools located inside population centres as urban schools and all schools located outside population centres as rural schools.

School access to fast-food outlets. School access to fastfood outlets was assessed as the number of fast-food outlets available within a street network distance buffer (i.e. a catchment area with a $750 \mathrm{~m}$ radius around the school location, based on the distance that approximates a $10 \mathrm{~min}$ walk for a secondary-school student) using the Network Analyst extension in ArcGIS 10.0 (ESRI, Redlands, CA, USA). A street network distance buffer is a surface delimited by distances measured along the available street networks in every direction from the location of the school (see Fig. 1). Students appear to conceptualize their schools' surroundings ${ }^{(34,35)}$ based on a distance of approximately $750 \mathrm{~m}$ along street networks ${ }^{(36,37)}$, similar to a half-a-mile threshold used in other studies conducted in the USA ${ }^{(22,38,39)}$. School access to fast-food outlets was then dichotomized into 'low access' ('access to 0 or 1 food outlets') and 'high access' ('access to 2 or more food outlets').

\section{Individual-level variables}

Sociodemographic variables included students' sex and age (dichotomized into ' 13 years old or younger' and '14 years old or older'), family status (categorized into 'other', 'lone-parent', 'shared custody', 'reconstituted' and 'twoparent'), students' perceived health status (categorized into 'poor or fair', 'good' and 'very good or excellent') and parental education (categorized into 'less than high school', 'high school' and 'college- or university-level education').

\section{Analyses \\ We conducted a multilevel logistic regression analysis using the GLIMMIX procedure in the statistical software package SAS version 9.3 to investigate the association between school fast-food access and JCL, after controlling}




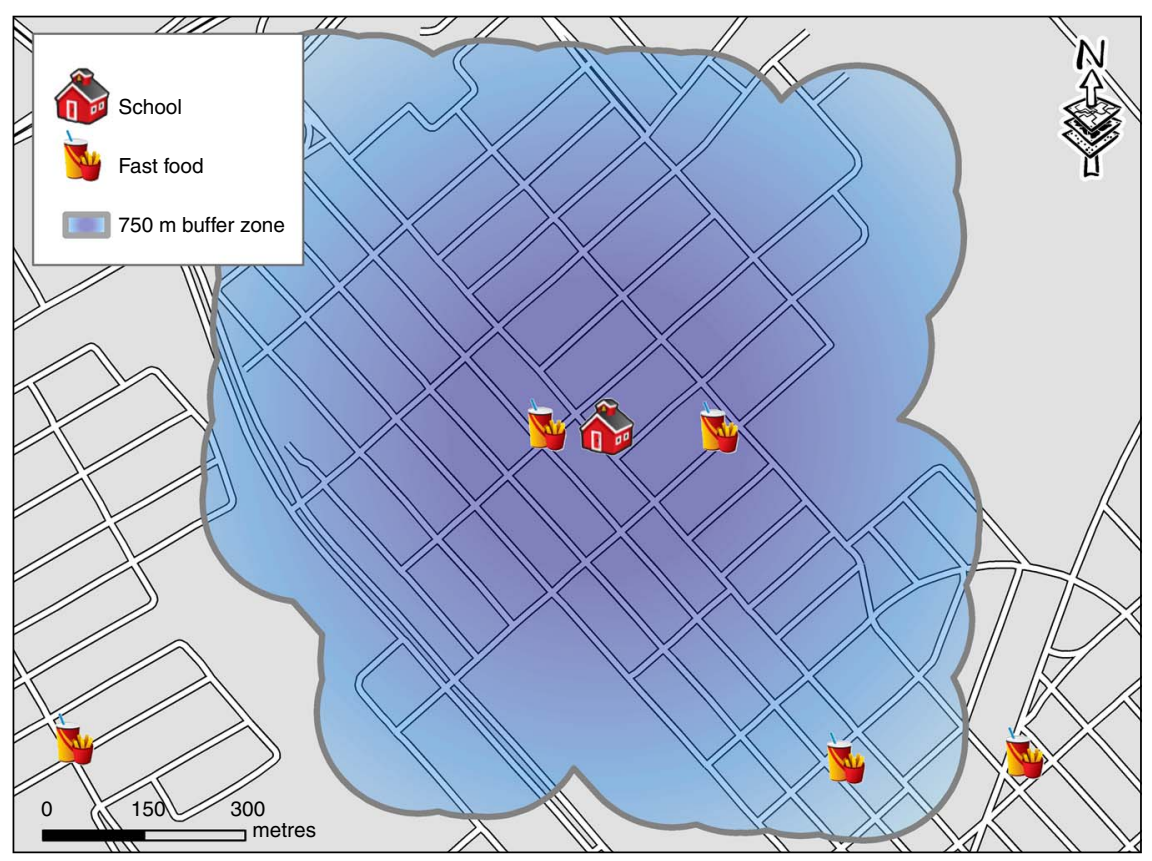

Fig. 1 (colour online) Example of a $750 \mathrm{~m}$ street network distance buffer around a school

for covariates. We modelled the probability of students consuming junk food at lunch two or more times during the previous week, based on a binomial distribution, a logit link and on the Newton-Raphson optimization technique ${ }^{(41)}$, to account for the clustering of students within schools. The Newton-Raphson technique allows one to determine whether the variables included last have an additional contribution in explaining the outcome variable over and above the contribution of the variables already included in the model. The analysis consisted of four successive models. In Model A, we included only the random intercept (the null model), to account for any school-level effect. In Model $\mathrm{B}$, we controlled for individual-level sociodemographic covariates (students' sex, age, family status, students' perceived health status and parental education), to investigate the extent to which school-level differences were explained by the characteristics of the students affiliated with each school. In Model C, we controlled for school-level covariates: we added the school index of material deprivation and the school urban/rural status in the analysis, to investigate whether the school-level differences were explained by differences in the school environment's deprivation and urban/rural status. In Model D, we added the school access to fast food.

To partition the variance between the two levels of analysis (students and schools) and provide information on the role of the school clustering in a multilevel logistic regression analysis, we employed measures that assess clustering in the case of a binary outcome, such as the median odds ratio (MOR) index and the $80 \%$ interval odds ratio (IOR) index ${ }^{(42,43)}$. To calculate the MOR, we first needed to consider all possible pairs of areas included in the sample and then perform calculations for each possible two students with similar covariates but attending two different schools. We then calculated the lowest and the highest odds of excess JCL for these two students and computed the odds ratios between the student with the higher odds of excess JCL and the student with the lower odds of excess JCL for this pair of students. After performing the calculations for all possible pairs of students attending different schools, we obtained a distribution of odds ratios and we further took the median value of this distribution, which represents the MOR index.

Therefore, the MOR index captures the change (in median) in the odds ratios for two students in two randomly selected schools, with all other covariates being maintained the same. Specifically, the MOR index was calculated using the formula:

$$
\mathrm{MOR}=\exp \left(0.95 \times \sqrt{V_{\mathrm{s}}}\right)
$$

where $V_{\mathrm{s}}$ is the school-level variance. A MOR of 1 indicates no variability in the probability of excess JCL (i.e. JCL of at least twice per week between schools) that can be attributed to the differences between schools. A large MOR value indicates a large difference in a student's probability of excess JCL that can be attributed to the differences between schools ${ }^{(42,44,45)}$.

Proportional change in variance (PCV) was also calculated using the formula:

$$
\mathrm{PCV}=\frac{V_{\mathrm{s} 1} V_{\mathrm{s} 2}}{V_{\mathrm{s} 1}} \times 100,
$$

where $V_{\mathrm{s} 1}$ represents the school-level variance of the null model and $V_{\mathrm{s} 2}$ represents the school-level variance of the 
model with all variables. A decrease in the school-level variance indicates that the model is explained in part by the variability in the JCL between the schools ${ }^{(44)}$.

\section{Results}

\section{Descriptive statistics}

We found that $78 \%$ of students reported lower JCL (0 or 1 times) and $22 \%$ of students reported higher JCL ( 2 times or more) in the previous week. Table 1 illustrates the characteristics of the students, their families, as well as their school environments. The sample consisted of a similar proportion of boys $(51.2 \%)$ and girls (48.8\%), with a majority of the students being 14 years or older (72.4\%) and enjoying excellent self-rated health (69.1\%). More than half of the students had two-parent families (58.1\%) and only $8 \cdot 1 \%$ of the students had parents with educational attainment lower than high-school education. Almost one-third of the students attended a more deprived school (28.3\%) and the majority of the students (89.7\%) attended an urban school. Finally, about $40 \%$ of the

Table 1 Descriptive statistics (non-weighted variables) of the secondary-school students ( $n$ 26655), their families, as well as their school environments, Quebec, Canada, 2010-2011

\begin{tabular}{|c|c|c|}
\hline & $\%$ & $n$ \\
\hline \multicolumn{3}{|l|}{ Individual- and familial-level variables } \\
\hline $\begin{array}{l}\text { Junk food consumption during lunchtime } \\
2 \text { or more times weekly }\end{array}$ & $22 \cdot 0$ & 5172 \\
\hline \multicolumn{3}{|l|}{ Child's sex } \\
\hline Girls & $48 \cdot 8$ & 13317 \\
\hline Boys & $51 \cdot 2$ & 13338 \\
\hline Total & $100 \cdot 0$ & 26655 \\
\hline \multicolumn{3}{|l|}{ Child's age } \\
\hline 13 years or younger & $27 \cdot 6$ & 7498 \\
\hline 14 years or older & $72 \cdot 4$ & 19157 \\
\hline \multicolumn{3}{|l|}{ Family status } \\
\hline Two-parent & 58.1 & 15745 \\
\hline Reconstituted & 13.1 & 3574 \\
\hline Shared custody & $11 \cdot 0$ & 2947 \\
\hline Lone-parent & $16 \cdot 0$ & 3823 \\
\hline Other & 1.9 & 549 \\
\hline \multicolumn{3}{|l|}{ Children's perceived health status } \\
\hline Very good or excellent & 69.1 & 18628 \\
\hline Good & $26 \cdot 2$ & 6783 \\
\hline Poor or fair & 4.8 & 1217 \\
\hline \multicolumn{3}{|l|}{ Parental education } \\
\hline College- or university-level education & 73.7 & 17299 \\
\hline High school & $18 \cdot 2$ & 4644 \\
\hline Less than high school & $8 \cdot 1$ & 2076 \\
\hline \multicolumn{3}{|l|}{ School-level variables } \\
\hline \multicolumn{3}{|l|}{ School deprivation index } \\
\hline Less deprived & 71.7 & 16872 \\
\hline More deprived & $28 \cdot 3$ & 9783 \\
\hline \multicolumn{3}{|l|}{ School urban/rural status } \\
\hline Rural & $10 \cdot 3$ & 5164 \\
\hline Urban & $89 \cdot 7$ & 21491 \\
\hline \multicolumn{3}{|l|}{$\begin{array}{l}\text { School access to fast-food outlets } \\
\text { (no. of fast-food outlets within a } 750 \mathrm{~m} \\
\text { street network distance buffer) }\end{array}$} \\
\hline Low access (access to 0 or 1 food outlets) & 58.8 & 16914 \\
\hline High access (access to 2 or more food outlets) & $41 \cdot 2$ & 9727 \\
\hline
\end{tabular}

students had access to two or more fast-food outlets within $750 \mathrm{~m}$ of their school.

\section{Results of the bierarchical analyses}

Model A (Table 2) shows a high value of 2.31 for the MOR that indicates a significant between-school variability in student likelihood of excess JCL.

Model B shows a higher likelihood of JCL being associated with students' individual characteristics, specifically with being a boy $(\mathrm{OR}=1.56 ; 95 \%$ CI 1.39, 1.74), having a shared custody family $(\mathrm{OR}=1 \cdot 20 ; 95 \%$ CI 1.03 , 1.39) or a family other than two-parent, reconstituted, shared custody and lone-parent $(\mathrm{OR}=1 \cdot 73$; $95 \%$ CI $1 \cdot 19$, $2 \cdot 52)$, being in good self-perceived health (OR $=1 \cdot 17 ; 95 \%$ CI $1 \cdot 05,1 \cdot 30)$, or poor or fair self-perceived health $(\mathrm{OR}=$ 1.47; $95 \%$ CI 1.18, 1.83). Also, Model B shows an association between a higher JCL and having parents with high-school education ( $O R=1 \cdot 26 ; 95 \%$ CI $1 \cdot 11,1.43$ ) or with an educational attainment lower than high school $(\mathrm{OR}=1 \cdot 31 ; 95 \% \mathrm{CI} 1.08,1.60)$. The PCV in the odds of JCL across students $(-2.56 \%)$ and schools (100\%) can be attributed to the individual compositional covariates we included in Model B, suggesting that part of the clustering of JCL within schools is attributable the composition of the schools by students' individual characteristics.

Model C shows that the school variables of urban/rural status and deprivation explained an important portion of the variability observed in the JCL between schools. The PCV coefficient was changed to $20 \cdot 51 \%$ between models $\mathrm{A}$ and $\mathrm{C}$, indicating that school urban/rural status and deprivation explain $20 \%$ of the variance in the JCL between schools. A higher likelihood of JCL of 2 times or more per week is associated with higher school deprivation $(\mathrm{OR}=1.44 ; 95 \% \mathrm{CI} 1.22,1.71)$ and with urban school status $(\mathrm{OR}=1.39 ; 95 \% \mathrm{CI} 1 \cdot 16,1.66)$.

Model D shows that school fast-food exposure explained $3 \%$ of the variance in the JCL between schools. The PCV coefficient changed to $24.35 \%$ between models $\mathrm{A}$ and $\mathrm{D}$, indicating that school urban/rural status, deprivation and fast-food exposure explain $24 \%$ of the variance in JCL between schools. Students of schools with two or more fast-food outlets within $750 \mathrm{~m}(\mathrm{OR}=1.50$; $95 \% \mathrm{CI}$ $1.28,1.75)$ have a higher likelihood of JCL of 2 times or more per week after controlling for student-, family- and school-level variables.

\section{Discussion}

The present study aimed to evaluate the association between school exposure to fast-food outlets within $750 \mathrm{~m}$ and JCL among secondary-school students attending public schools in the province of Quebec. We found that a higher access to fast-food outlets around school (of two or more outlets) within $750 \mathrm{~m}$ was associated with a higher 
Table 2 Association between exposure to school fast-food outlet access and junk food consumption during lunchtime 2 or more times weekly among secondary-school students in Quebec, Canada, 2010-2011

\begin{tabular}{|c|c|c|c|c|c|c|c|c|c|c|}
\hline & \multicolumn{2}{|c|}{ Bivariate analyses } & \multicolumn{2}{|c|}{ Model A } & \multicolumn{2}{|c|}{ Model B } & \multicolumn{2}{|c|}{ Model C } & \multicolumn{2}{|r|}{ Model D } \\
\hline & OR & $95 \% \mathrm{Cl}$ & OR & $95 \% \mathrm{Cl}$ & OR & $95 \% \mathrm{Cl}$ & OR & $95 \% \mathrm{Cl}$ & OR & $95 \% \mathrm{Cl}$ \\
\hline \multicolumn{11}{|l|}{ Individual- and familial-level variables } \\
\hline \multicolumn{11}{|l|}{ Student's sex } \\
\hline Girls (ref.) & \multicolumn{2}{|c|}{1.00} & & & \multicolumn{2}{|c|}{1.00} & \multicolumn{2}{|c|}{1.00} & \multicolumn{2}{|r|}{1.00} \\
\hline Boys & 1.42 & $1.27,1.58$ & & & 1.56 & $1.39,1.74$ & 1.49 & $1.33,1.68$ & 1.49 & $1.33,1.68$ \\
\hline \multicolumn{11}{|l|}{ Student's age } \\
\hline 13 years or younger (ref.) & \multicolumn{2}{|c|}{1.00} & & & \multicolumn{2}{|c|}{1.00} & \multicolumn{2}{|c|}{1.00} & \multicolumn{2}{|r|}{1.00} \\
\hline 14 years or older & $1 \cdot 17$ & $1.02,1.34$ & & & $1 \cdot 10$ & $0.97,1.26$ & $1 \cdot 12$ & $0.97,1.30$ & $1 \cdot 12$ & $0.97,1.29$ \\
\hline \multicolumn{11}{|l|}{ Family status } \\
\hline Two-parent (ref.) & \multicolumn{2}{|c|}{1.00} & & & \multicolumn{2}{|c|}{1.00} & \multicolumn{2}{|c|}{1.00} & \multicolumn{2}{|r|}{1.00} \\
\hline Reconstituted (4) & 1.09 & $0.93,1.27$ & & & 1.06 & $0.90,1.24$ & 1.05 & $0.89,1.25$ & 1.05 & $0.89,1.25$ \\
\hline Shared custody (3) & 1.24 & $1.08,1.43$ & & & 1.20 & $1.03,1.39$ & 1.20 & $1.02,1.41$ & 1.20 & $1.02,1.41$ \\
\hline Lone-parent (2) & 1.08 & $0.91,1.28$ & & & 1.21 & $0.96,1.31$ & 1.11 & $0.93,1.33$ & 1.11 & $0.93,1.33$ \\
\hline Other (1) & 1.76 & $1.29,2.42$ & & & 1.73 & $1 \cdot 19,2.52$ & 1.67 & $1.14,2.42$ & 1.56 & $1.08,2.25$ \\
\hline \multicolumn{11}{|l|}{ Student's perceived health } \\
\hline Very good or excellent (ref.) & \multicolumn{2}{|c|}{1.00} & & & \multicolumn{2}{|c|}{1.00} & \multicolumn{2}{|c|}{1.00} & \multicolumn{2}{|r|}{1.00} \\
\hline Good (2) & $1 \cdot 16$ & $1.05,1.28$ & & & 1.17 & $1.05,1.30$ & 1.21 & $1.09,1.42$ & 1.21 & $1.09,1.35$ \\
\hline Poor or fair (1) & 1.31 & $1.04,1.67$ & & & 1.47 & $1.18,1.83$ & 1.49 & $1.17,1.88$ & 1.49 & $1.18,1.88$ \\
\hline Parental education & & & & & & & & & & \\
\hline College- or university-level education (ref.) & & 0 & & & & 00 & & 00 & & 1.00 \\
\hline High school (2) & 1.28 & $1.13,1.46$ & & & 1.26 & $1.11,1.43$ & 1.24 & $1.09,1.42$ & 1.25 & $1.09,1.43$ \\
\hline Less than high school (1) & 1.30 & $1.07,1.57$ & & & 1.31 & $1.08,1.60$ & 1.27 & $1.04,1.56$ & 1.26 & $1.03,1.55$ \\
\hline School-level variables & & & & & & & & & & \\
\hline School deprivation index & & & & & & & & & & \\
\hline Less deprived (ref.) & & 0 & & & & & & 00 & & 1.00 \\
\hline More deprived (1) & 1.36 & $1 \cdot 16,1.61$ & & & & & 1.44 & $1 \cdot 22,1 \cdot 71$ & 1.39 & $1.18,1.63$ \\
\hline School urban/rural status & & & & & & & & & & \\
\hline Rural (ref.) & & 0 & & & & & & 00 & & 1.00 \\
\hline Urban (1) & 1.20 & $1.02,1.41$ & & & & & 1.39 & $1.16,1.66$ & 1.27 & $1.06,1.52$ \\
\hline School access to fast-food outlets (no. of fast-food & ets with & $50 \mathrm{~m}$ street & ork dis & ance buffer) & & & & & & \\
\hline Low access (access to 0 or 1 food outlets) & & & & & & & & & & 1.00 \\
\hline High access (access to 2 or more food outlets) & 1.55 & $1.32,1.82$ & & & & & & & 1.50 & $1.28,1.75$ \\
\hline School-level variance (SE) & & & 0.78 & & 0.80 & & 0.62 & & 0.59 & 0.05 \\
\hline MOR $(80 \%-$ IOR\%) & & & $2 \cdot 31$ & $1 \cdot 29,2 \cdot 36$ & $2 \cdot 34$ & $1 \cdot 72,2 \cdot 36$ & $2 \cdot 11$ & $1 \cdot 71,2 \cdot 14$ & 2.07 & $1 \cdot 72,2 \cdot 10$ \\
\hline PCV & & & & Ref. & & $56 \%$ & & $51 \%$ & & $24.35 \%$ \\
\hline
\end{tabular}

Ref., reference category; MOR, median odds ratio; IOR, interval for odds ratio; PCV, change in variance. 
JCL after controlling for variables characterizing the student (e.g. age, gender and perceived health), their families (family status and parental education) and their schools (school status and deprivation).

Other studies have also reported significant associations between the characteristics of the built environments around schools and youths' nutrition; for instance, one study $^{(46)}$ found higher access to supermarkets to be associated with a healthier diet, while another study ${ }^{(36)}$ found an association between the presence of food retailers near schools and the eating habits of young people during their lunch hour. Students aged 11-14 years in London, Ontario ${ }^{(17,47)}$ were more likely to buy fast food and to have unhealthy diets if they attended schools with a higher access to fast-food outlets around schools.

Conversely, a systematic review ${ }^{(48)}$ identified four studies finding no relationship between dietary outcomes and similar school food exposures in a similar age group as our sample ${ }^{(22,39,49,50)}$. One US study ${ }^{(39)}$ looked at the frequency of eating from fast-food restaurants in the previous month in relation to outlet density within $800 \mathrm{~m}$ street network buffers with an extra $150 \mathrm{~m}$ buffer around the street network surrounding schools. Another US study ${ }^{(49)}$ looked at the daily servings of fast food during the previous day in relation to the number of outlets within circular $800 \mathrm{~m}$ radius buffers. A third US study ${ }^{(22)}$ looked at fast-food consumption during the previous day in relation to school proximity within $800 \mathrm{~m}$ from at least one fastfood restaurant. The fourth study ${ }^{(50)}$, conducted in the Netherlands, looked at the daily soft drink and snack consumption in relation to the number of food outlets within a $500 \mathrm{~m}$ circular buffer around each school. These studies provided different results perhaps because the food environments differ between Canada and the USA and the Netherlands. Also, the use of different definitions and metrics for outcomes (i.e. the limitations surrounding the respondents' subjective definition of a serving in one study, leaving room for interpretation ${ }^{(49)}$ ) and food categories, as well as for exposures (the buffer construction; i.e. 'sausage (39) $v$. circular ${ }^{(49,50)}$ ), the potential inaccuracy in capturing exposures (e.g. presence of shortcuts/pathways that are usually not captured by GIS in assessing accessibility of locations), the different degrees of accuracy of databases (i.e. use of commercial databases more prone to error as opposed to use of a governmental listing), the likely differential lag between data collection and exposure data collection may explain differences in results.

Like other studies, we did not consider other food outlets (e.g. convenience stores, ethnic/specialty stores, supermarkets) where students may purchase sugarsweetened beverages, potato crisps or other inexpensive junk foods. Presence of such outlets may have contributed to our findings, especially because $64 \%$ of the public schools in Quebec have at least one convenience store within $750 \mathrm{~m}^{(19)}$. Future studies should consider more food sources to provide a better portrait of the food opportunities available around schools ${ }^{(51)}$.

Also, there may be other factors that could mitigate the effect of the food environment around schools, such as open/closed school policy (i.e. whether pupils are allowed to leave school premises during lunch breaks), safety of the school neighbourhood (i.e. presence of traffic-calming measures), school transportation models (i.e. whether students actively or passively commute to school) and school food environment policies (i.e. type of vending machine food, physical activity in schools). For instance, open/closed policy in schools is associated with higher fast-food consumption $^{(39)}$. In Quebec, there are opportunities for children to acquire other types of food apart from the types of food available in their school's immediate vicinity. Even though children may attend schools with higher access to unhealthy foods, they may engage in more walking and other physical activity if the school environment offers such opportunities or they may actively commute to school and/or to potentially healthier food outlets if such behaviours are encouraged. For instance, $51 \%$ of public schools in Quebec have at least one recreational facility within $750 \mathrm{~m}, 35 \%$ of the secondary schools have higher walkability surrounding environments within $750 \mathrm{~m}$, and $43 \%$ of public schools have at least one bike path within $750 \mathrm{~m}^{(19)}$. Also, because students in public schools in Quebec may leave school premises during lunch, it appears that using various transportation means may influence student's dietary behaviours more than access to food outlets ${ }^{(48,49)}$. School boards offer school transportation services for students before, after school and at lunchtime to provide students with the opportunity to eat their meals at home ${ }^{(52)}$; eligibility includes children residing more than $1.4 \mathrm{~km}$ from the school for the English ${ }^{(53)}$ and $1.6 \mathrm{~km}$ for the French-language elementary schools ${ }^{(54)}$ in Montreal. In addition, the local and provincial governments in Quebec created partnerships for replacing actual travel modes with more active forms of transportation, such as the 'On the Move to School' programme or the BIXI bikesharing programme in Montreal ${ }^{(55)}$

Our results suggest that the food environments surrounding schools can be considered viable targets of intervention for improving nutrition among secondaryschool students. We found a similar proportion for the fast-food outlets access of two or more outlets within $750 \mathrm{~m}$ around school (41.2\%) as recent studies, indicating a high level of exposure. Kestens and Daniel ${ }^{(56)}$ found a proportion of $50.4 \%$ of schools having at least one fast-food outlet within $750 \mathrm{~m}$ in metropolitan Montreal, similar to the results of a study conducted in British Columbia which found $54 \%$ of schools having at least one fast-food outlet within $800 \mathrm{~m}^{(57)}$. In Chicago, USA, $80 \%$ of schools had at least one fast-food restaurant within $800 \mathrm{~m}^{(58)}$. Robitaille and colleagues ${ }^{(20)}$ found that $37 \%$ of public schools in Quebec are located within $640 \mathrm{~m}$ from a fast-food outlet. In London, Ontario ${ }^{(35)}, 42$ and $28 \%$ of schools had two or more fast-food outlets within $500 \mathrm{~m}$ 
buffers, calculated based on Euclidean and street network distance, respectively. Another study ${ }^{(59)}$ conducted in Los Angeles County, USA, found that $64.8 \%$ of schools had at least one fast-food outlet within $800 \mathrm{~m}$. In another US study ${ }^{(60)}$ of more than 30000 schools located in fifty states, $37 \cdot 12 \%$ of schools had at least one fast-food outlet within $805 \mathrm{~m}$ of the school.

Some potential directions of action are recommended. One direction involves using zoning to limit the presence of certain types of food outlets (e.g. fast-food outlets, convenience stores) around schools ${ }^{(61)}$; such zoning policies appear to improve availability of fruits and vegetables and favour healthy nutrition in communities ${ }^{(62)}$. Communities have limited power in taking such decisions in Quebec because the local legislation does not allow limiting the presence of certain commercial uses, even the ones that are deemed detrimental for health, such as certain chains of fast-food restaurants ${ }^{(63,64)}$. However, the quality of the food options available around schools can be improved ${ }^{(64)}$, because the urbanism legislation allows communities to limit the presence of certain commercial uses if they are considered incompatible with the local architectural context. Currently, there are three initiatives of the Public Health Agency of Quebec which aim to limit access to fast-food outlets around schools ${ }^{(65,66)}$.

Another direction would be improving the food options available around schools by limiting the menus available in restaurants to menus that provide healthier options only. In the USA, several interventions were implemented focusing on modifying food options of the existing fast-food establishments and convenience stores, by promoting food options with a higher nutritional value, while reducing the availability of food options with lower nutritional value. Such interventions indicated an increase in the offer, sale, promotion and knowledge about food with higher nutritional value ${ }^{(67)}$. However, banning certain types of restaurant on the basis of the menu offered ${ }^{(68)}$ is not allowed in Quebec, so even though municipalities and community organizations influence food environments in larger contexts (e.g. at the neighbourhood or at the city level), their influence on the school environments is limited ${ }^{(68)}$. Therefore, collaborative initiatives are necessary between schools and communities.

In addition to the built environment around schools, we found that students' individual characteristics (sex, age and perceived health), familial characteristics (family status and parental education) and school characteristics (urban/rural status and deprivation) are associated with JCL. Thus, an integrative intersectoral approach focusing on individuals and environments, which cross-cuts sociocultural, economic and political dimensions, is necessary. Interventions could target individuals by offering cooking classes to improve the cooking and food preparation competencies of the youths and their families ${ }^{(70)}$. Also, because students of schools with higher deprivation appear to be more exposed to fast-food options ${ }^{(19,20,56,58,59,70-73)}$, interventions to support the creation and operation of low-cost restaurants that offer healthier and subsidized lunches (e.g. coupons) are necessary ${ }^{(74)}$, particularly in school environments with high access to fast foods and high deprivation. Such interventions also need media support to help change the social norms around eating unhealthy food and raise awareness about the benefits of healthier lifestyles. These initiatives need to be informed by theoretically sound frameworks that involve all stakeholders (e.g. parents, students, teachers) to influence youths to eat their lunch in school, in cafeterias free of junk foods, as illustrated recently by Beaulieu and Godin ${ }^{(75)}$. Most importantly, a coherent policy strategy for supportive built environments for healthy lifestyles is needed in Canada, to provide local planning authorities with instruments for developing the necessary legislative frameworks. This strategy needs to stipulate various tax incentives to support healthy eating as well as various constraints through zoning to limit access to fast-food outlets ${ }^{(76)}$. It also needs to involve several legislative approaches, at the governmental (e.g. introduction of a junk food tax to help subsidize healthy foods, particularly among children from lower socioeconomic status families; ban on trans fats), corporate (e.g. sponsoring healthy food campaigns) and school levels (e.g. banning junk food advertisements and sales in schools $)^{(77)}$. Even though there is strong support for more comprehensive school health policies focusing on the schools within their community context ${ }^{(76)}$, there are only a few examples of rezoning to limit fast-food access in Canada, mostly in Quebec (e.g. a by-law implemented against drive-through around food outlets in residential areas in Montreal ${ }^{(78)}$, zoning by-law revision processes in Gatineau and in Lavaltrie, and a by-law implemented to restrict fast-food outlets in certain zones in Baie-Saint-Paul $\left.{ }^{(79)}\right)$.

\section{Limitations and strengths}

The current study has several limitations. It is a cross-sectional study that does not allow for establishing causality. Even though the self-reported measure of JCL is frequently used ${ }^{(32,80)}$, this measure involves a certain degree of bias, with girls potentially underestimating and boys overestimating consumption. Our exposure measure (i.e. access to fast-food outlets) was collected in 2009, while our outcome measure (i.e. students' junk food consumption) was collected in 2010-2011; thus the food environment may have changed in the year between data collection for exposure and outcome.

Also, data on the location of the food outlets may underor overestimate their presence ${ }^{(81,82)}$, but our use of MAPAQ data may reduce such a bias ${ }^{(83)}$ because a government database is likely more accurate and more up-to-date than existing commercial directories, as shown recently ${ }^{(51)}$.

Finally, we only analysed food environments around schools, but future studies should also consider residential environments, within an activity space approach focusing 
on all environments that youths frequent daily ${ }^{(18,84,85)}$. However, such information was not available for the current study. Our study's strengths include the use of a large representative sample for the province of Quebec and the use of hierarchical models that account for students' enrolment in schools.

\section{Conclusion}

A large proportion of secondary-school students in Quebec are exposed to fast-food outlets within $750 \mathrm{~m}$ of schools, which was associated with junk food consumption at lunch of two or more times weekly. This indicates that the food environments around schools constitute a target for interventions that promote healthy eating among youths. Communities may use zoning instruments to limit the presence of certain types of food commerce around schools. Interventions can also target the food options available in existing food establishments to offer choices of greater nutritional value.

\section{Acknowledgements}

Acknowledgements: The authors would like to thank Johanne Laguë for reviewing an earlier version of this manuscript. Financial support: This study was possible by the financial contribution of the Ministry of Health and Social Services of Quebec. N.C. was supported by a Fellowship from the Research Centre of the University of Montréal Hospital Centre (CRCHUM) at the time of data analysis and writing of the manuscript. The funders had no role in the design, analysis or writing of this article. Conflict of interest: Authors declare no financial or nonfinancial competing interests. Authorship: All authors contributed equally to the study design and analyses. B.L. and E.R. created the spatial measures. I.T. conducted the statistical analyses with input from all authors. N.C. and E.R. drafted the initial form of the manuscript. All authors commented the manuscript draft. Ethics of human subject participation: This study was conducted according to the guidelines laid down in the Declaration of Helsinki and all procedures involving human subjects/patients were approved by the Institute of Statistics of Quebec's Ethics Committee, led by Pierre Durand (the Ethics Committee's president). Written informed consent was obtained from all survey participants.

\section{References}

1. Jørgensen T, Capewell S, Prescott E et al. (2013) Populationlevel changes to promote cardiovascular health. Eur J Prev Cardiol 20, 409-421.

2. Pouliou T \& Elliott SJ (2010) Individual and socioenvironmental determinants of overweight and obesity in urban Canada. Health Place 16, 389-398.
3. World Health Organization (2009) Global Health Risks. Mortality and Burden of Disease Attributable to Selected Major Risks. Geneva: WHO.

4. Public Health Agency of Canada (2011) Obesity in Canada: A Joint Report from the Public Health Agency of Canada and the Canadian Institute for Health Information. Ottawa, ON: Canadian Institute for Health Information.

5. Lamontagne P \& Hamel D (2009) Le poids corporel chez les enfants et adolescents du Québec: de 1978 à 2005. Montréal, QC: Institut national de santé publique du Québec.

6. Camirand H, Blanchet C \& Pica LA (2012) Habitudes alimentaires. Quebec City, QC: Gouvernement du Québec, Institut de la statistique du Québec.

7. Taylor JP, Evers S \& McKenna M (2005) Determinants of healthy eating in children and youth. Can J Public Health 96, Suppl. 3, S22-S29.

8. Office of Consumer Affairs (2004) The Consumer Trends Report. Industry Canada Research Paper. Ottawa, ON: Government of Canada.

9. Statistics Canada (2012) Survey of Household Spending, 2010. The Daily, 25 April 2012. http://www.statcan.gc.ca/ daily-quotidien/120425/dq120425a-eng.pdf (accessed July 2015).

10. GE Capital Franchise Finance (2014) 2014 Canadian Chain Restaurant Industry Review. http://www.restaurantinvest. $\mathrm{ca} /$ site/restaurant_invest/assets/pdf/2014_canadian_chain_ restaurant_industry_review.pdf (accessed July 2015).

11. Powell LM \& Nguyen BT (2013) Fast-food and full-service restaurant consumption among children and adolescents: effect on energy, beverage, and nutrient intake. JAMA Pediatr 167, 14-20.

12. Rosenheck R (2008) Fast food consumption and increased caloric intake: a systematic review of a trajectory towards weight gain and obesity risk. Obes Rev 9, 535-547.

13. Sallis JF, Floyd MF, Rodríguez DA et al. (2012) Role of built environments in physical activity, obesity, and cardiovascular disease. Circulation 125, 729-737.

14. Bauman AE, Reis RS, Sallis JF et al. (2012) Correlates of physical activity: why are some people physically active and others not? Lancet 380, 258-271.

15. Bergeron P \& Reyburn S (2010) L'impact de l'environnement bâti sur l'activité physique, l'alimentation et le poids. Montréal, QC: Institut national de santé publique du Québec.

16. Laxer RE \& Janssen I (2013) The proportion of excessive fast-food consumption attributable to the neighbourhood food environment among youth living within $1 \mathrm{~km}$ of their school. Appl Physiol Nutr Metab 39, 480-486.

17. He M, Tucker P, Irwin JD et al. (2012) Obesogenic neighbourhoods: the impact of neighbourhood restaurants and convenience stores on adolescents' food consumption behaviours. Public Health Nutr 15, 2331-2339.

18. Van Hulst A, Barnett TA, Gauvin L et al. (2012) Associations between children's diets and features of their residential and school neighbourhood food environments. Can J Public Health 103, eS48-eS54.

19. Lalonde B \& Robitaille É (2014) L'environnement bâti autour des écoles et les habitudes de vie des jeunes. État des connaissances et portrait du Québec. Montréal, QC: Institut national de santé publique du Québec.

20. Robitaille É, Bergeron P \& Lasnier B (2009) Analyse géographique de l'accessibilité des restaurants-minute et des dépanneurs autour des écoles publiques québécoises. Montréal, QC: Institut national de santé publique du Québec.

21. Buck C, Börnhorst C, Pohlabeln H et al. (2013) Clustering of unhealthy food around German schools and its influence on dietary behavior in school children: a pilot study. Int J Behav Nutr Phys Act 10, 65. 
22. Davis B \& Carpenter C (2009) Proximity of fast-food restaurants to schools and adolescent obesity. Am J Public Health 99, 505-510.

23. Gebremariam MK, Andersen LF, Bjelland M et al. (2012) Does the school food environment influence the dietary behaviours of Norwegian 11-year-olds? The HEIA study. Scand I Public Health 40, 491-497.

24. Shields M \& Shooshtari S (2001) Determinants of Self-Perceived Health. Catalogue no. 82-003. Ottawa, ON: Statistics Canada.

25. Quebec Ministry of Health and Social Services (2010) Vision de la saine alimentation - Pour la création d'environnements alimentaires favorables à la santé. http://publications. msss.gouv.qc.ca/msss/fichiers/2010/10-289-06F.pdf (accessed August 2015)

26. Quebec Institute of Statistics (2015) Quebec Health Survey of High School Students (QHSHSS) 2010. http://www. qhshss.stat.gouv.qc.ca/ (accessed August 2015).

27. Pica LA, Traoré I, Bernéche F et al. (2012) Habitudes alimentaire, dans L'Enquête québécoise sur la santé des jeunes du secondaire 2010-2011, Le visage des jeunes d'aujourd'bui: leur santé physique et leurs habitudes de vie. Quebec City, QC: Gouvernement du Québec, Institut de la statistique du Québec.

28. Pampalon R, Hamel D, Gamache P et al. (2009) A deprivation index for health planning in Canada. Chronic Dis Can 29, 178-191.

29. Statistics Canada (2012) Census Dictionary: Census year, 2011. https://www12.statcan.gc.ca/census-recensement/2011/ref/ dict/98-301-X2011001-eng.pdf (accessed July 2015).

30. Statistics Canada (2015) Population centres. https://www12. statcan.gc.ca/census-recensement/2011/ref/dict/geo049aeng.cfm (accessed June 2015).

31. Boutelle KN, Fulkerson JA, Neumark-Sztainer D et al. (2007) Fast food for family meals: relationships with parent and adolescent food intake, home food availability and weight status. Public Health Nutr 10, 16-23.

32. French SA, Story M, Neumark-Sztainer D et al. (2001) Fast food restaurant use among adolescents: associations with nutrient intake, food choices and behavioral and psychosocial variables. Int J Obes Relat Metab Disord 25, 1823-1833.

33. Pereira MA, Kartashov AI, Ebbeling CB et al. (2005) Fastfood habits, weight gain, and insulin resistance (the CARDIA study): 15-year prospective analysis. Lancet 365, 36-42.

34. Baillargeon G (2005) La carte des unités de peuplement de 2003. Quebec City, QC: Ministère de l'Éducation, du Loisir et du Sport, Direction de la recherche, des statistiques et des indicateurs.

35. Gilliland JA, Rangel CY, Healy MA et al. (2012) Linking childhood obesity to the built environment: a multi-level analysis of home and school neighbourhood factors associated with body mass index. Can J Public Health $\mathbf{1 0 3}$, eS15-eS21

36. Seliske L, Pickett W, Rosu A et al. (2013) The number and type of food retailers surrounding schools and their association with lunctime eating behaviours in students. Int J Behav Nutr Phys Act 10, 19.

37. Forsyth A, Larson N, Lytle L et al. (2012) LEAN-GIS Protocols. Local Environment for Activity and Nutrition-Geographic Information Systems, Version 2.1, January 2012. http:// designforhealth.net/wp-content/uploads/2012/12/LEAN_ Protocol_V2_1_010112rev.pdf (accessed July 2015).

38. Forsyth A, Van Riper D, Larson N et al. (2012) Creating a replicable, valid cross-platform buffering technique: the sausage network buffer for measuring food and physical activity built environments. Int J Health Geogr 11, 14.

39. Forsyth A, Wall M, Larson N et al. (2012) Do adolescents who live or go to school near fast-food restaurants eat more frequently from fast-food restaurants? Health Place $\mathbf{1 8}$ 1261-1269.

40. Sánchez BN, Sanchez-Vaznaugh EV, Uscilka A et al. (2012) Differential associations between the food environment near schools and childhood overweight across race/ ethnicity, gender, and grade. Am J Epidemiol 175 1284-1293.

41. SAS Institute Inc (2009) The MCMC procedure. In SAS/STAT ${ }^{\circledR}$ 9.2 User's Guide. 2nd ed. Cary, NC: SAS Institute, Inc.

42. Merlo J, Yang M, Chaix B et al. (2005) A brief conceptual tutorial on multilevel analysis in social epidemiology: investigating contextual phenomena in different groups of people. I Epidemiol Community Health 59, 729-736.

43. Larsen K \& Merlo J (2005) Appropriate assessment of neighborhood effects on individual health: integrating random and fixed effects in multilevel logistic regression. Am J Epidemiol 161, 81-88.

44. Esser M, Lack N, Riedel C et al. (2013) Relevance of hospital characteristics as performance indicators for treatment of very-low-birth-weight neonates. Eur J Public Health 24, 739-744.

45. Halonen JI, Kivimäki M, Pentti J et al. (2012) Quantifying neighbourhood socioeconomic effects in clustering of behaviour-related risk factors: a multilevel analysis. PLOS One 7, e32937.

46. Smith D, Cummins S, Clark C et al. (2013) Does the local food environment around schools affect diet? Longitudinal associations in adolescents attending secondary schools in East London. BMC Public Health 13, 70.

47. He M, Tucker P, Gilliland J et al. (2012) The influence of local food environments on adolescents' food purchasing behaviors. Int J Environ Res Public Health 9, 1458-1471.

48. Williams J, Scarborough P, Matthews A et al. (2014) A systematic review of the influence of the retail food environment around schools on obesity-related outcomes. Obes Rev 15, 359-374.

49. An R \& Sturm R (2012) School and residential neighborhood food environment and diet among California youth. Am J Prev Med 42, 129-135.

50. van der Horst K, Timperio A, Crawford D et al. (2008) The school food environment: associations with adolescent soft drink and snack consumption. Am J Prev Med 35, 217-223

51. Lake AA, Burgoine T, Greenhalgh F et al. (2010) The foodscape: classification and field validation of secondary data sources. Health Place 16, 666-673.

52. Legis Quebec (2016) The Quebec Education Act. Quebec City, QC: Government of Quebec; available at http:// legisquebec.gouv.qc.ca/en/ShowDoc/cs/I-13.3

53. English Montreal School Board (2013) Transportation. http://www.emsb.qc.ca/en/services_en/pages/transportation_ en.asp (accessed August 2016).

54. Commission scolaire de Montréal (2016) Organisation scolaire. http://csdm.ca/secondaire/organisation-scolaire/ (accessed August 2016).

55. Federation of Canadian Municipalities (2011) Changing Transportation Behavioour in Quebec. https://www.fcm.ca/ Documents/case-studies/GMF/Transport-Canada/Change TranspoBehaviourQC_EN.pdf (accessed August 2016).

56. Kestens Y \& Daniel $\bar{M}$ (2010) Social inequalities in food exposure around schools in an urban area. Am J Prev Med 39, 33-40.

57. Black JL \& Day M (2012) Availability of limited service food outlets surrounding schools in British Columbia. Can J Public Health 103, e255-e259.

58. Austin SB, Melly SJ, Sanchez BN et al. (2005) Clustering of fast-food restaurants around schools: a novel application of spatial statistics to the study of food environments. Am J Public Health 95, 1575-1581. 
59. Simon PA, Kwan D, Angelescu A et al. (2008) Proximity of fast food restaurants to schools: do neighborhood income and type of school matter? Prev Med 47, 284-288.

60. Zenk SN \& Powell LM (2008) US secondary schools and food outlets. Health Place 14, 336-446.

61. Centers for Disease Control and Prevention (2015) Zoning to encourage healthy eating. http://www.cdc.gov/phlp/ winnable/zoning_obesity.html (accessed July 2015).

62. Mayo ML, Pitts SB \& Chriqui JF (2013) Associations between county and municipality zoning ordinances and access to fruit and vegetable outlets in rural North Carolina, 2012. Prev Chronic Dis 10, E203.

63. Bourdeau M \& LeChasseur M-A (2009) La malbouffe chez les jeunes: une solution municipale à un problème social. Urbanité Winter issue, 29-33.

64. Paquin S (2009) Le zonage municipal: un outil contribuant à créer un environnement bâti favorable aux saines habitudes alimentaires. Montréal, QC: Institut national de santé publique du Québec.

65. Allard M (2012) Malbouffe et écoles: les villes peuvent agir. La Presse, 22 October 2012.

66. Association pour la santé publique du Québec (2013) Urbanisme et environnement alimentaire autour des écoles: une règlementation pour limiter l'implantation des restaurants rapides. http://www.aspq.org/documents/file/rapport2013-du-projet-zonage-(2).pdf (accessed June 2015).

67. Gittelsohn J, Rowan M \& Gadhoke P (2012) Interventions in small food stores to change the food environment, improve diet, and reduce risk of chronic disease. Prev Chronic Dis 9. E59.

68. Association pour la santé publique du Québec (2012) La zone-école et l'alimentation: des pistes d'action pour le monde municipal. Montréal, QC: ASPQ.

69. Chenhall C (2010) Improving Cooking and Food Preparation Skills: A Synthesis of the Evidence to Inform Program and Policy Development. http://www.hc-sc.gc.ca/fn-an/ nutrition/child-enfant/cfps-acc-synthes-eng.php (accessed May 2016).

70. Day PL \& Pearce J (2011) Obesity-promoting food environments and the spatial clustering of food outlets around schools. Am J Prev Med 40, 113-121.

71. Seliske LM, Pickett W, Boyce WF et al. (2009) Density and type of food retailers surrounding Canadian schools: variations across socioeconomic status. Health Place 15, 903-907.

72. Sturm R (2008) Disparities in the food environment surrounding US middle and high schools. Public Health 122, 681-690.
73. Walker RE, Block J \& Kawachi I (2014) The spatial accessibility of fast food restaurants and convenience stores in relation to neighborhood schools. Appl Spatial Anal Policy 7, 169-182.

74. Bergeron P \& Paquette M-C (2014) Les mesures de repas scolaires subventionnés et leurs impacts sur l'alimentation et le poids corporel des jeunes: expériences étrangères et perspectives pour le Québec. Montréal, QC: Institut national de santé publique du Québec.

75. Beaulieu D \& Godin G (2012) Development of an intervention programme to encourage high school students to stay in school for lunch instead of eating at nearby fast-food restaurants. Eval Program Plann 35, 382-389.

76. Raine KD, Muhajarine N, Spence JC et al. (2012) Coming to consensus on policy to create supportive built environments and community design. Can J Public Health 103, eS5-eS8.

77. Eisenberg MJ, Atallah R, Grandi SM et al. (2011) Legislative approaches to tackling the obesity epidemic. CMAJ 183, 1496-1500.

78. Quebec Public Health Association (2014) Limiting businesses with drive-through service. The experience of the Borough of Saint-Laurent in Montreal. http://www.aspq. org/documents/file/aspq_summary-sheet_regstl.pdf (accessed August 2016).

79. Quebec en Forme (2012) Modifying the built environment to promote healthy eating among youth. Highlights of the Research no. 8, July 2012. http://www.quebecenforme. org/media/103607/08_research_summary.pdf (accessed October 2016).

80. Larson N \& Story M (2009) A review of environmental influences on food choices. Ann Behav Med 38, 56-73.

81. Liese AD, Colabianchi N, Lamichhane AP et al. (2010) Validation of 3 food outlet databases: completeness and geospatial accuracy in rural and urban food environments. Am J Epidemiol 172, 1324-1333.

82. Paquet C, Daniel M, Kestens Y, Léger K et al. (2008) Field validation of listings of food stores and commercial physical activity establishments from secondary data. Int J Behav Nutr Phys Act 5, 58.

83. Cummins S \& Macintyre S (2009) Are secondary data sources on the neighbourhood food environment accurate? Case-study in Glasgow, UK. Prev Med 49, 527-528.

84. Kestens Y, Lebel A, Daniel M et al. (2010) Using experienced activity spaces to measure foodscape exposure. Health Place 16, 1094-1103.

85. Larsen K, Gilliland J \& Hess PM (2012) Route-based analysis to capture the environmental influences on a child's mode of travel between home and school. Ann Assoc Am Geogr 102, 1348-1365. 